\title{
Phenol Degradation Potential of Bacteria Isolated From Extreme Habitats
}

\author{
Dezső-Róbert Fikó ${ }^{1,2}$, Erika Kovács ${ }^{2}$, Szabolcs Szilveszter ${ }^{2}$, Tamás Felföldi ${ }^{2,3}$, István Máthé2 \\ ${ }^{1}$ Faculty of Applied Chemistry and Material Sciences, University Politehnica of Bucharest \\ RO-011061, Polizu 1-7 Bucharest, Romania \\ fiko_robi@yahoo.com \\ ${ }^{2}$ Faculty of Economics, Socio-Human Sciences and Engineering, Sapientia Hungarian University of Transylvania \\ RO-530104, Libertății Sq. nr. 1, Romania \\ kovacserika@sapientia.siculorum.ro; szilveszterszabolcs@sapientia.siculorum.ro; matheistvan@ sapientia.siculorum.ro \\ ${ }^{3}$ Department of Microbiology, Eötvös Loránd University \\ Pázmány Péter sétány 1/C, Budapest, Hungary \\ tamas.felfoldi@gmail.com
}

\section{Extended Abstract}

Phenol is a pollutant that is usually found in many industrial wastewaters (pulp and paper manufacturing, pharmaceutical industries, coal processing plants, oil refineries) and represent a risk for the environment and human health, due to its toxic, carcinogenic and mutagenic properties [1,2]. Therefore, it is essential to remove phenolic compounds from polluted environments, for that, microbial degradation process is a cost effective solution [3].

The objective of our research was to investigate biological phenol degradation using different bacterial strains isolated from extreme habitats with the final aim to use them in bioremediation. One of the sampling sites was a municipal solid waste landfill leachate treatment bioreactor (near Odorheiu Secuiesc town, Romania) and the other was a contaminated salt mine lake (Ocna Mureş town, Romania).

Samples were inoculated into Mineral Medium culture broth containing phenol or bisphenol-A as sole carbon source. From the enrichment cultures, the surface of R2A medium was inoculated to isolate morphologically different bacterial colonies. For the taxonomic identification of isolated strains, the $16 \mathrm{~S}$ rRNA gene sequencing method was used [4].

In total, 50 bacterial strains were isolated: 20 strains were obtained from Mineral Medium with bisphenol-A (representing 17 species) and 30 bacterial strains were obtained from phenol-containing Mineral Medium (representing 15 species). The most common genera were Simplicispira, Paracoccus and Halomonas. Due to its low 16S rRNA gene similarity, one Simplicispira strain represents potentially new species to science.

The biodegradation capacity of the identified strains was analyzed using various phenol concentrations. Some of the studied strains had high phenol degradation capacity (initial phenol concentration from 500 to $1000 \mathrm{mg} / \mathrm{L}$ in the growth medium), while other strains showed no growth and no degradation at lower $(100 \mathrm{mg} / \mathrm{L})$ initial phenol concentration.

\section{References}

[1] K. M. Basha, A. Rajendran and V. Thangavelu, "Recent advances in the Biodegradation of Phenol: A review," Asian J. Exp. Biol. Sci., vol. 1, no. 2, pp. 219-234, 2010.

[2] Y. F. Wang, X. L. Wang, H. Li, K. F. Lin, P. Wang, J. Yang, Y. D. Liu, Z. Y. Sun, L. H. Fan and Z. M. Wu, "Treatment of high salinity phenol-laden wastewater using a sequencing batch reactor containing halophilic bacterial community," Int. Biodeter. Biodegr, vol. 93, pp. 138-144, 2014.

[3] A. Haddadi and M. Shavandi, "Biodegradation of phenol in hypersaline conditions by Halomonas sp. strain PH2-2 isolated from saline soil," Int. Biodeter. Biodegr, vol. 85, pp. 29-34, 2013.

[4] B. J. Tindall, R. Rossello-Mora, H. J. Busse, W. Ludwig, and P. Kämpfer, "Notes on the characterization of prokaryote strains for taxonomic purposes," Int. J. Syst. Evol. Microbiol, vol. 60, pp. 249-266, 2010. 